\title{
Yield Response of Cassava (Manihot esculenta Crantz) to One and Two Banded Fertilizer Applications on a Limed Guyana Peaty Clay Soil ${ }^{1}$
}

\author{
A. H. Wahab and M. A. Lugo-López ${ }^{2}$
}

\begin{abstract}
A trial was conducted on a Guyana peaty clay to determine the effects of lime and split NPK applications on cassava yields. All plots received broadcast lime at the rate of $6.72 \mathrm{t} / \mathrm{ha}$. Treatments were lime only (control); $400 \mathrm{~kg} / \mathrm{ha}$ in a 3:1:2 ratio of $\mathrm{N}, \mathrm{P}_{2} \mathrm{O}_{5}$ and $\mathrm{K}_{2} \mathrm{O}$ one month after planting; and the same amount banded as two equal doses at 1 month and 5 months after planting.

There was no significant increase in fresh root weight attributable to the fertilizer treatments. However, stems and leaves increased in fresh matter by 110 and $35 \%$, respectively when plots received one full dose of NPK at 1 month and when the same amount split in two equal split doses, was applied at 1 month and 5 months after planting. The likelihood of an improper NPK balance associated with increased vegetative growth is discussed.
\end{abstract}

\section{INTRODUCTION}

This paper reports the results of a preliminary trial to ascertain the yield response of cassava to one and two applications of a standard fertilizer mixture.

Mechanization and variety trials to assess the viability of cassava cultivation on Guyana's agriculturally poor but extensive peaty soils commenced in 1975 at the Enmore Sugar Estate. These soils are mediumto coarse-structured, porous and susceptible to brief floodings during periods of sustained heavy rainfall.

If these soils are to be developed for agriculture, appropriate management techniques must be developed. The right kinds and amounts of fertilizer and soil amendment must be applied at the right time and in the right way.

\section{MATERIALS AND METHODS}

An experiment was conducted on a soil locally classified as Inki clay $\# 100^{3}$. This soil is extremely acid ( $\mathrm{pH} \mathrm{3-4)}$ and its buffer capacity is high. Cation exchange capacity within the $0-15 \mathrm{~cm}$ soil layer approximates 16

'Manuscript submitted to Editorial Board October 5, 1978.

2 Former Crop Development Officer, Project Evaluation Unit, Guyana Sugar Corporation Ltd., Georgetown Guyana, now Agricultural Research Specialist, Inter American Institute of Agricultural Sciences, OAS, Kingston, Jamaica; and Professor and Soil Scientist (Ret.), Agricultural Experiment Station, University of Puerto Rico, Mayagüez Campus, Mayagüez, P. R. This work was financed by the Guyana Sugar Corporation, Limited, with technical support from the Department of Agronomy, Cornell University, Ithaca, N. Y., under USAID research contract ta-c-1104.

${ }^{3}$ Steele, J. G. and Randin, H. N., Soil resources of Guyana, Ministry of Agriculture, Central Agricultural Station, Mon. Repos, 1975. 
meq/100 g, of which exchangeable bases account for $40 \%$. Available P and $\mathrm{K}$ levels are low; total $\mathrm{N}$ is adequate and $\mathrm{C} / \mathrm{N}$ ratio approaches 10 . Inki clay \#100 consists of a surface matt of $1-20 \mathrm{~cm}$ of peaty clay. The upper subsoil is a soft gray to greenish gray clay which is underlined by peat.

The trial was conducted from May 1975 to June 1976 on plots located $10 \mathrm{~km}$ south of the Enmore Sugar Estate. The area was permanently flooded until early 1974 when the necessary drainage facilities were installed. Following drainage, the area was cleared of weeds and land was plowed, harrowed and ridged.

Two treatments consisted of one level of a fertilizer mixture (198 kg N as urea, $67 \mathrm{~kg} \mathrm{P}_{2} \mathrm{O}_{5}$ and $134 \mathrm{~kg} \mathrm{~K} \mathrm{~K}_{2} \mathrm{O} / \mathrm{ha}$ ) which was added to lime at the rate of $6.72 \mathrm{t} / \mathrm{ha}$, as aragonite, and was applied to plots as follows: 1) (control) lime only (6.72 t/ha) 1 month after planting; 2) full dose of $\mathrm{N}, \mathrm{P}, \mathrm{K}$ and lime 1 month after planting; and 3) one-half of N,P,K and lime 1 month after planting and one-half dose of N,P,K 5 months after planting.

Each application of fertilizer was banded or broadcast $15 \mathrm{~cm}$ away from the plants and incorporated 4 to $5 \mathrm{~cm}$. A completely randomized design with four replicates was used. Plants were spaced at $.9 \times .9 \mathrm{~m}$ in plots containing 5 rows of 10 plants each. Ridges were spaced $3 \mathrm{ft}$ apart.

Planting material of variety Brancha Butterstick was machine cut into uniform lengths of $15 \mathrm{~cm}$, immersed in a suspension of Dithane M-45 $(0.04 \%$ a.i.) and Monocrotophos $(0.06 \%$ a.i.) for $0.5 \mathrm{~h}$ and planted inclined on the ridge, 5 to $6 \mathrm{~cm}$ below the soil surface.

Plots were manually weeded at one, four and nine months after planting. Serious outbreaks of hornworm (Erynnis ello) were observed following heavy and continuous showers in the months of September, October, November and December 1975. After reinfestation, there were fortnightly applications of Monocrotophos (0.5 litter a.i./ha) which resulted in effective control. Moderately severe attacks of the shoot fly (Silba pendula) were observed the ninth month and persisted through harvest. Trichlorofon (Dipterex) at lg a.i./ha at three weekly intervals controlled this pest.

Plots were harvested 12 months after planting and the weight of fresh roots, stems, and leaves was recorded.

\section{RESULTS AND DISCUSSION}

Data on total fresh weight of roots, stems and leaves are presented in table 1 . There was no significant increase in root yields from plots that

\footnotetext{
${ }^{4}$ Trade names in this publication are used only to provide specific information. Mention of a trade name does not constitute a warranty of equipment or materials by the Agricultural Experiment Station of the University of Puerto Rico, nor is this mention a statement of preference over other equipment or materials.
} 
had been fertilized as compared to those that had received lime only. Yields ranged from $14.60 \mathrm{t} / \mathrm{ha}$ for the unfertilized plots to $15.25 \mathrm{t} / \mathrm{ha}$ for plots that received lime and two split applications of $\mathrm{N}, \mathrm{P}, \mathrm{K}$.

Fresh weight of stems and leaves was significantly greater (12.94 t/ha) in plots which had been limed and fertilized with one full dose of N,P,K; vs. $6.17 \mathrm{t} / \mathrm{ha}$ in plots that had been only limed. Hence, it would appear that added N,P,K served to enhance vegetative growth without concommitantly increasing fresh root weight. Such a situation is not uncommon when too high a rate of $\mathrm{N}$ relative to $\mathrm{K}$ is applied to plants.

The N,P,K fertilizer analysis found to be best for cassava on peat soils in West Malaysia ${ }^{5}$ was used for these studies. Optimum levels of lime and NPK must be determined to realize significant benefits from fertilizers.

TABLE 1.-Fresh matter yields of cassava roots, stems + leaves at 12 months following lime; and fertilizer applications at 1 and 5 months after planting

\begin{tabular}{|c|c|c|}
\hline Treatment & $\begin{array}{l}\text { Fresh root yields } \\
\text { (11955 plants/ha) } \\
\text { at } 12 \text { months }\end{array}$ & $\begin{array}{l}\text { Fresh weight } \\
\text { (to } / \text { ha) of } \\
\text { stems + leaves } \\
\text { at harvest }\end{array}$ \\
\hline & \multicolumn{2}{|c|}{ metric ton/ha } \\
\hline $\begin{array}{l}\text { Lime only }(6.72 \mathrm{t} / \mathrm{ha}) \text {, applied } 1 \text { month } \\
\text { after planting }\end{array}$ & $14.40^{\mathrm{a} .1}$ & $6.17^{\mathrm{a}}$ \\
\hline $\begin{array}{l}\text { Lime }(6.73 \mathrm{t} / \mathrm{ha})+400 \mathrm{~kg} / \mathrm{ha} \text { of } 3 \mathrm{~N} \text { : } \\
1 \mathrm{P}_{2} \mathrm{O}_{5}: 2 \mathrm{~K}_{2} \mathrm{O} \text { applied } 1 \text { month after } \\
\text { planting }\end{array}$ & $14.60^{A}$ & 12.94 \\
\hline $\begin{array}{l}\text { Lime }(6.72 \mathrm{t} / \mathrm{ha})+200 \mathrm{~kg} / \mathrm{ha} \text { of } 3 \mathrm{~N} \text { : } \\
1 \mathrm{P}_{2} \mathrm{O}_{5}: 2 \mathrm{~K}_{2} \mathrm{O} \text { applied at } 1 \text { month fol- } \\
\text { lowed by application of a similar dose } \\
\text { of fertilizers at } 5 \text { months after planting }\end{array}$ & $15.25^{\mathrm{a}}$ & $8.34^{\prime \prime}$ \\
\hline
\end{tabular}

\section{RESUMEN}

En Guyana se realizó un experimento durante 12 meses en el suelo Inki arcilloso, rico en materia orgánica. El objetivo del estudio era determinar el efecto de aplicaciones de cal y de abono en los rendimientos de la yuca. Todas las parcelas recibieron cal a razón de $6.72 \mathrm{Tm} /$ ha. Los tres tratamientos fueron como sigue: cal únicamente (control); $400 \mathrm{~kg} / \mathrm{ha}$ de un abono en una proporción 3:1:2 de $\mathrm{N}, \mathrm{P}_{2} \mathrm{O}_{5}$ y $\mathrm{K}_{2} \mathrm{O}$ aplicado en franjas en una sola dosis un mes después de la siembra, y la misma cantidad aplicada también franjas dividida en partes iguales al mes y a los 5 meses después de la siembra. No hubo diferencias significativas en los rendimientos que se puedan atribuir a los tratamien-

\footnotetext{
${ }^{5}$ Chew, W. Y., Varieties and NPK fertilizers for tapioca (Manihot utilissima Pohl.) on peat, Malays. Agri. J. 47(4): 433-491, 1970.
} 
tos. Sin embargo, se registraron aumentos en materia verde de los tallos y hojas de 110 y $35 \%$, respectivamente, en las parcelas que recibieron NPK en una sola dosis un mes después de la siembra e igual cantidad dividida en dos dosis, un mes y 5 meses después de la siembra. Es probable que un balance inadecuado de NPK estuviese asociado con aumentos en el desarrollo vegetativo. 